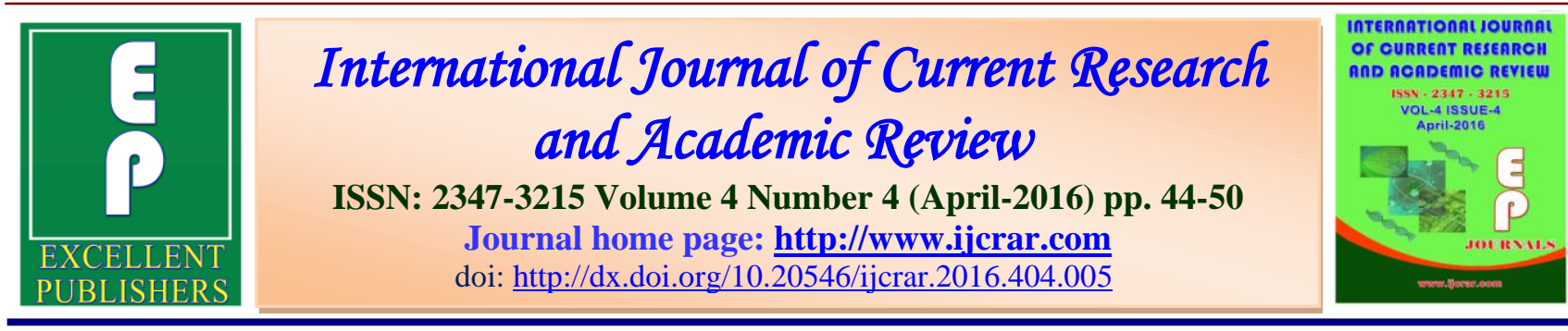

\title{
Study of the Insect Pest Complex of Rainfed Rice Crop-Ecosystem of Manipur Valley, India
}

Jenita, Th D.C. Ray ${ }^{1}$, K.I. Singh ${ }^{2}$, S.Sanjay $\operatorname{Singh}^{3}$ and Th. Rocky ${ }^{4}$

${ }^{1}$ Department of Ecology and Environmental Science, Assam University, Silchar, Assam788011, India

${ }^{2}$ Department of Entomology, Central Agricultural University, Imphal, Manipur-795004, India

${ }^{3}$ ICAR, NEH Region, Lamphelpat, Imphal, Manipur- 795004, India

${ }^{4}$ Department of Floriculture, Medicinal and Aromatic Plants, Uttar Banga Krishi

Viswavidyalaya, Pundibari, Cooch Behar - 736165, West Bengal, India

*Corresponding author

\begin{tabular}{|l|l|}
\hline \multirow{2}{*}{ KEYWORDS } & A B S T R A C T \\
\cline { 2 - 2 } $\begin{array}{l}\text { Insect pest } \\
\text { complex, }\end{array}$ & $\begin{array}{l}\text { The replicated field investigations were made to study the insect pest } \\
\text { complex at the Rice Research Farm, College of Agriculture, Central }\end{array}$ \\
Scirpophaga & Agricultural University, Imphal during Kharif season of 2010 and 2011. \\
Cnaphalocrocis & During the study, about 30 insect pest species were recorded to infest Rice in \\
medinalis. & $\begin{array}{l}\text { Manipur and of which Asian gall fly, Orseolia oryzae Wood-Mason, Yellow } \\
\text { stem borer, Scirpophaga incertulas Walker, leaf folder, Cnaphalocrocis }\end{array}$ \\
& $\begin{array}{l}\text { medinalis Guenee, caseworm, Nymphula depunctalis, whorl maggot, } \\
\text { Hydrellia philippina Ferina, small grasshopper, Oxya chinensis Walker, green }\end{array}$ \\
& $\begin{array}{l}\text { leafhopper, Nephotettix virescens, gundhi bug, Leptocorisa acuta T, } \\
\text { swarming caterpillar, Spodoptera mauritia and Army worm, Mythimna } \\
\text { separata Walker are of the major importance inflicting the crop. }\end{array}$ \\
\hline
\end{tabular}

\section{Introduction}

Rice, Oryza sativa Linnaeus, the grain of life and staple food of more than $60 \%$ of the world population is cultivated in 111 countries of the world in varied edaphic and meteorological condition. It is grown under different Agro ecosystem s such as bunded uplands and water logged lowlands mostly under rainfed conditions. India has got world's largest rice growing areas with
43.93 million hectares with production of 91.61 million tones (Anonymous, 2001). In Manipur, rice is the staple food of entire population and mainly grown during the Kharif season in an area of 1,76,310 hectares, producing 435.9 thousand tones with a productivity of $2413.52 \mathrm{~kg} / \mathrm{ha}$ (Anonymous, 2005). The population of the 
state is about 2.39 millions with the total estimated rice requirement of 5.49 lakh tones. Thus, the state has to produce additional rice of about 1.62 lakh tones to meet the requirement of the ever- increasing population of the state.

Though, the average per hectare yield of the state is higher than that of national average, in comparison to other major rice growing states of the country, the Kharif rice productivity in Manipur is still low. There is a sharp decline in the overall growth rate of food production from $4.23 \%$ during 1967 1978 to $3.77 \%$ during $1979-91$ and $2.96 \%$ during last five years (Paroda, 2006). To meet the demand of the burgeoning population it is of paramount importance that a second breakthrough in food grain production and productivity advance is to be achieved in the country. There are quite a number of biotic and abiotic and socioeconomic constraints in production of rice, of which insect pest attack is one of the major cause at various stages of crop growth (Peter, 2015). This crop is attacked by 385 species of insects in India causing 31.5$86.0 \%$ losses in yield (Gunathilagaraj and Kumar, 1997).

In Manipur, among the pyralid pests, the leaf folder, yellow stem borer plays a key role in yield reduction (Ram et al., 1981 and Barwal et al., 1994). It was reported that in Rewa District, Madhya Pradesh there were twelve found damaging rice fields during wet season of which Gundhi bug> WBPH> Grasshopper $>$ Stem borer were regular pests, while Hispa> armyworm> horned caterpillar $>$ Rice caseworm were sporadic pests (Mishra et al., 2010). Stem borers, Leaf folders and white backed plant hopper were observed major pests damaging the crop in Basmati rice in the Sheikhupura district of Pakistan (Ramzan et al., 2007)

\section{Materials and Methods}

A field experiment was conducted for two consecutive years during kharif season of 2010 and 2011 at the Rice Research Farm, College of Agriculture, Central Agricultural University, Imphal to study the insect pest complex of rainfed rice crop- ecosystem of Manipur. The soil type was clay loam in texture and acidic in reaction having ph value of 5.5. All the recommended agronomic practices for Kharif rice cultivation were adopted for growing the experimental crop.

The experiment was laid out as simple field trial with the susceptible variety 'Leimaphou', one month old seedling were transplanted in $20 \mathrm{~cm} \times 15 \mathrm{~cm}$ spacing on the first week of July Kharif, 2010 and 20011. The plot size was $50 \mathrm{~m}^{2}$ areas. Periodic observations on the occurrence of insects was recorded at weekly interval starting from 15 days after sowing of seed (Nursery stage) till crop mature (Main field) on 20 randomly selected hills or one square meter cropping areas of plots during the experimental period. The mean monthly metrological data recorded during the period of investigation are presented in Table 1.

\section{Results and Discussion}

Prevailing abiotic factors, particularly temperature, relative humidity and rainfall and bio control agents, viz., parasitoids, predators and entomophilic pathogens, crops and cropping patterns followed and pest resistant/susceptible varieties grown and crop management including fertilizer management practices adopted in a locality are known to exert profound influence on growth and development of arthropod crop pests and their population build up. 
Int.J.Curr.Res.Aca.Rev.2016; 4(4): 44-50

Table.1 Mean Meteorological Data Recorded during the Experimental Period (2010 and 2011)

\begin{tabular}{|c|c|c|c|c|c|c|c|c|c|c|}
\hline \multirow[t]{3}{*}{ Month } & \multicolumn{4}{|c|}{$\begin{array}{c}\text { Temperature } \\
\left({ }^{\circ} \mathrm{C}\right)\end{array}$} & \multicolumn{4}{|c|}{$\begin{array}{c}\text { Relative Humidity } \\
(\%)\end{array}$} & \multirow{2}{*}{\multicolumn{2}{|c|}{$\begin{array}{c}\text { Rainfall } \\
\text { (mm) }\end{array}$}} \\
\hline & \multicolumn{2}{|c|}{ Maximum } & \multicolumn{2}{|c|}{ Minimum } & \multicolumn{2}{|c|}{ Morning } & \multicolumn{2}{|c|}{ Evening } & & \\
\hline & 2010 & 2011 & 2010 & 2011 & 2010 & 2011 & 2010 & 2011 & 2010 & 2011 \\
\hline May & 27.9 & 28.2 & 20.1 & 19.2 & 89.7 & 85.8 & 83.8 & 68.0 & 6.2 & 8.9 \\
\hline June & 27.3 & 29.8 & 22.0 & 22.0 & 94.5 & 92.2 & 75.5 & 80.5 & 7.9 & 12.8 \\
\hline July & 29.0 & 30.7 & 22.7 & 22.0 & 92.9 & 92.3 & 83.3 & 77.7 & 9.6 & 9.6 \\
\hline August & 29.6 & 30.4 & 22.6 & 21.8 & 92.8 & 92.9 & 86.2 & 77.6 & 3.3 & 9.0 \\
\hline September & 28.6 & 30.3 & 21.6 & 21.4 & 93.6 & 89.4 & 87.4 & 70.1 & 8.7 & 4.9 \\
\hline October & 27.6 & 28.7 & 18.5 & 17.8 & 92.4 & 87.3 & 87.2 & 61.5 & 6.3 & 1.6 \\
\hline November & 25.3 & 27.0 & 12.7 & 9.2 & 90.1 & 86.2 & 83.8 & 47.6 & 0.4 & 0.0 \\
\hline
\end{tabular}

Table.2 Insect Pest Species Observed in Rainfed Rice var. 'Leimaphou’ during Experimental Years of Kharif, 2010 and 2011

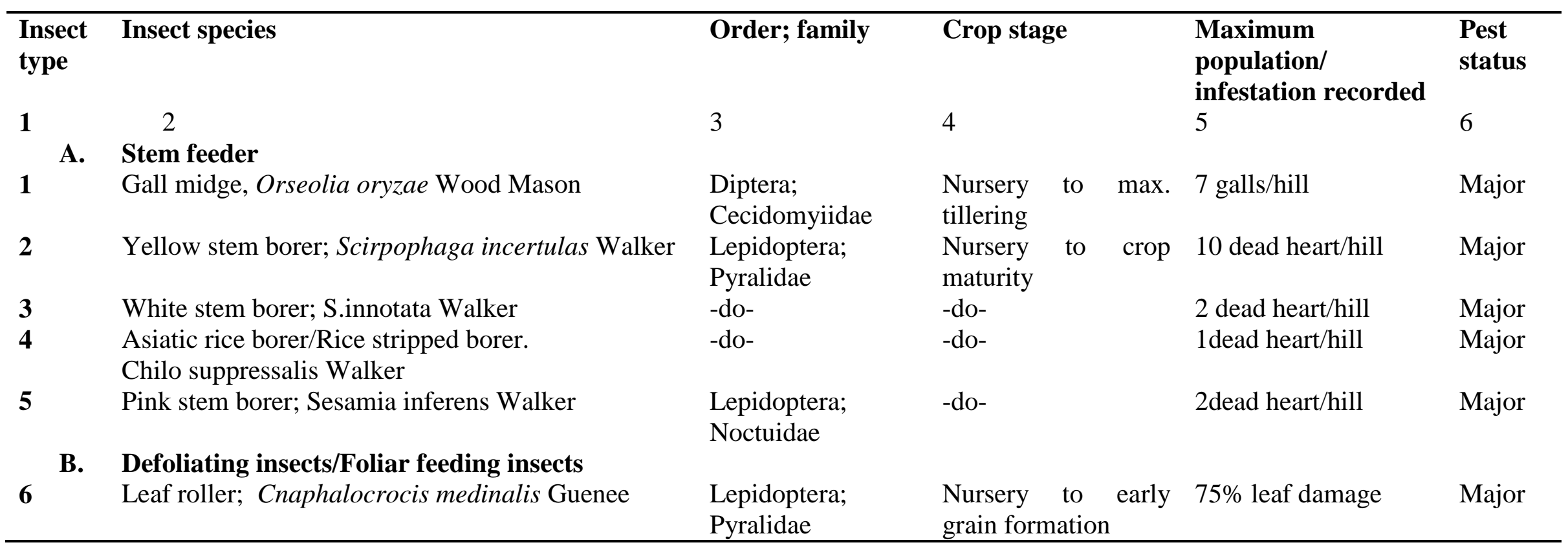


Int.J.Curr.Res.Aca.Rev.2016; 4(4): 44-50

\begin{tabular}{|c|c|c|c|c|c|}
\hline$\overline{7}$ & Rice case worm, Nymphula depuncyalis Guenee & $\begin{array}{l}\text { Lepidoptera; } \\
\text { Pyralidae }\end{array}$ & $\begin{array}{l}\text { Nursery to crop } \\
\text { maturity }\end{array}$ & 10 green cases & Major \\
\hline 8 & Rice whorl maggot, Hyderellia philippina Ferina & & Nursery to flowering & $55 \%$ leaf damage & Major \\
\hline 9 & Rice horned caterpillar, Melanitis ismene Guenee & $\begin{array}{l}\text { Lepidoptera; } \\
\text { Nymphalidae }\end{array}$ & Nursery to flowering & 1 larva/20 hills & Minor \\
\hline 10 & Rice skipper, Pelopidae methias Fabricius & $\begin{array}{l}\text { Lepidoptera; } \\
\text { Hesperidae }\end{array}$ & $\begin{array}{l}\text { Early vegetative to } \\
\text { early } \\
\text { formation }\end{array}$ & $2 \%$ leaf damage & Minor \\
\hline 11 & Rice hispa, Dicladispa armigera & $\begin{array}{l}\text { Coleoptera; } \\
\text { Chrysomelidae }\end{array}$ & $\begin{array}{l}\text { Early vegetative to } \\
\text { early } \\
\text { formation }\end{array}$ & 1 adult/sq.m & Minor \\
\hline 12 & Small grasshopper, Oxya chinensis Walker & $\begin{array}{l}\text { Orthoptera; } \\
\text { Acrididae }\end{array}$ & $\begin{array}{l}\text { Nursery to crop } \\
\text { maturity }\end{array}$ & 5 hopper/sweep & \\
\hline 13 & $\begin{array}{l}\text { Surface grasshopper, Atractomorphia crenulata } \\
\text { Fabricus }\end{array}$ & $\begin{array}{l}\text { Orthoptera; } \\
\text { Acrididae }\end{array}$ & $\begin{array}{l}\text { Nursery to crop } \\
\text { maturity }\end{array}$ & 2 hopper/ sweep & Minor \\
\hline 14 & Large grasshopper, Hieroglyphus banian Fabricius & $\begin{array}{l}\text { Orthoptera; } \\
\text { Acrididae }\end{array}$ & $\begin{array}{l}\text { Nursery to crop } \\
\text { maturity }\end{array}$ & 1 hopper/sweep & Minor \\
\hline & Root feeders & & & & \\
\hline 15 & White Grub, Holotrichia longipennis Biench & $\begin{array}{l}\text { Coleoptera; } \\
\text { Scrabaeididae }\end{array}$ & $\begin{array}{l}\text { Early vegetative to } \\
\text { crop maturity }\end{array}$ & 2 adults/50 hills & Minor \\
\hline 16 & Mole cricket, Gryllotalpa Africana Palisot deuvors & $\begin{array}{l}\text { Orthoptera; } \\
\text { Gryllotalpidae }\end{array}$ & $\begin{array}{l}\text { Nursery to late } \\
\text { vegetative }\end{array}$ & 1 cricket/sq.m & Minor \\
\hline & Sap suckers/Sucking insects & & & & \\
\hline 17 & Rice thrips, Thrips oryzae Willium & $\begin{array}{l}\text { Thysanoptera; } \\
\text { Thripidae }\end{array}$ & $\begin{array}{l}\text { Nursery to early } \\
\text { vegetative }\end{array}$ & 6 thrips/2 sweeps & Minor \\
\hline 18 & Green leaf hopper, Nephotettix virescens Distant & $\begin{array}{l}\text { Hemiptera; } \\
\text { Cicadelidae }\end{array}$ & $\begin{array}{l}\text { Nursery to early } \\
\text { grain formation }\end{array}$ & 20 hoppers/2 sweeps & \\
\hline 19 & N.nigropictus Stal. & $\begin{array}{l}\text { Hemiptera; } \\
\text { Cicadelidae }\end{array}$ & $\begin{array}{l}\text { Nursery to early } \\
\text { grain formation }\end{array}$ & 5 hoppers/2 sweeps & Minor \\
\hline 20 & Zig-zag leafhopper, Racilia dorsalis (Motsch.) & $\begin{array}{l}\text { Hemiptera; } \\
\text { Cicadelidae }\end{array}$ & $\begin{array}{l}\text { Nursery to early } \\
\text { grain formation }\end{array}$ & 5 hoppers/2 sweeps & Minor \\
\hline 21 & Brown shield bug, Dolycoris indicus Stal. & $\begin{array}{l}\text { Hemiptera; } \\
\text { Pentatomidae }\end{array}$ & $\begin{array}{l}\text { Early flowering to } \\
\text { soft drought }\end{array}$ & $1 \mathrm{bug} / 2$ sweeps & Minor \\
\hline
\end{tabular}


Int.J.Curr.Res.Aca.Rev.2016; 4(4): 44-50

\begin{tabular}{|c|c|c|c|c|c|}
\hline 22 & Rice shield bug, Menida histrio Fabricus & $\begin{array}{l}\text { Hemiptera; } \\
\text { Pentatomidae }\end{array}$ & $\begin{array}{l}\text { Early flowering to } \\
\text { soft drought }\end{array}$ & $1 \mathrm{bug} / 2$ sweeps & Minor \\
\hline 23 & Green shield bug, Nezara aviridula Linnaeus & $\begin{array}{l}\text { Hemiptera; } \\
\text { Pentatomidae }\end{array}$ & $\begin{array}{l}\text { Early flowering to } \\
\text { soft drought }\end{array}$ & $2 \mathrm{bug} / 2$ sweeps & Minor \\
\hline 24 & Rice black bug, Scotinophara coarctata Thunb. & $\begin{array}{l}\text { Hemiptera; } \\
\text { Pentatomidae }\end{array}$ & $\begin{array}{l}\text { Early flowering to } \\
\text { soft drought }\end{array}$ & $1 \mathrm{bug} / 2$ sweeps & Minor \\
\hline 25 & Brown bug, Eusarcocoris gultiger Westw. & $\begin{array}{l}\text { Hemiptera; } \\
\text { Pentatomidae }\end{array}$ & $\begin{array}{l}\text { Early flowering to } \\
\text { soft drought }\end{array}$ & $1 \mathrm{bug} / 2$ sweeps & Minor \\
\hline 26 & Coried bug, Riptortus sp. & $\begin{array}{l}\text { Hemiptera; } \\
\text { Pentatomidae }\end{array}$ & $\begin{array}{l}\text { Early flowering to } \\
\text { soft drought }\end{array}$ & $1 \mathrm{bug} / 2$ sweeps & Minor \\
\hline & Ear feeders & & & & \\
\hline 27 & Rice gundhi bug, Leptocorisa acuta Thunb & $\begin{array}{l}\text { Hemiptera; } \\
\text { Coriedae }\end{array}$ & $\begin{array}{l}\text { Panicle initiation to } \\
\text { grain formation }\end{array}$ & 15bugs/2 sweeps & Major \\
\hline 28 & $\begin{array}{l}\text { Tobacco/Rice swamming caterpillar, Spodoptera } \\
\text { mauritia Boisd }\end{array}$ & $\begin{array}{l}\text { Lepidoptere; } \\
\text { Noctuidae }\end{array}$ & $\begin{array}{l}\text { Flowering to grain } \\
\text { maturity }\end{array}$ & $10 \%$ ear head damage & Major \\
\hline 29 & S. litura Linnaeus & $\begin{array}{l}\text { Lepidoptere; } \\
\text { Noctuidae }\end{array}$ & $\begin{array}{l}\text { Flowering to grain } \\
\text { maturity }\end{array}$ & $3 \%$ ear head damage & Minor \\
\hline 30 & Rice army worm, Mythima seperata & $\begin{array}{l}\text { Lepidoptere; } \\
\text { Noctuidae }\end{array}$ & $\begin{array}{l}\text { Soft drought to grain } \\
\text { maturity }\end{array}$ & $15 \%$ ear head damage & Major \\
\hline
\end{tabular}


In view of the fact that there are variations in weather parameters and natural enemies of crop pests in different places during different seasons every years, variation in insect pests complex over time and space are considered as rule rather than an exception.

Various reasons, viz., delayed monsoon rains, application of high doses of nitrogenous fertilizers, drought with long spells of humid weather, indiscriminate and repeated application of insecticides, etc. has been attributed to the insect pest complex of Rice crop during the period of investigation (2010 and 2011).

During the study, altogether thirty different insect species have been observed inflicting the Rice crop var., 'Leimaphou' starting from germination to crop maturity, of which ten species, viz., Gall midge, Orseolia oryzae Wood Mason; Yellow stem borer, Scirpophaga incertulas Walker; Leaf roller, Cnaphalocrocis medinalis Guenee; Rice case worm, Nymphula depuncyalis Guenee; Rice whorl maggot, Hyderellia philippina Ferina; Small grasshopper, Oxya chinensis Walker; Green leaf hopper, Nephotettix virescens Distant; Rice gundhi bug, Leptocorisa acuta Thunb; Tobacco caterpillar, Spodoptera mauritia Boisd and Rice army worm, Mythima seperata Walker are the most important and regular pest of this crop in Manipur. The present findings are supported by the results of Ram et al. (1981) and Chaudhary et al. (2001).

Sontakke and Dash (2000) also reported that recent introduction of rice hybrids caused serious outbreak of many pests of Rice crop in Hirakud Command Area of western Orissa.

Different species of stem borer ( $S$. incertulas, $C$. suppressalis and Sesamia inferens). Gall midge (Oreseolia oryzae), leaf folder (C.medinalis), case worm ( $N$. depenctalis) and plant hoppers (Nilaparvata lugens and Sogatella furcifera) are the major pests inflicting severe damage to rice crops, which are encouraging the findings.

\section{References}

Anonymous. 2001. India 2001: A Reference. Annual Publication Division Ministry of Information and Broadcasting, Government of India, pp.385.

Anonymous. 2005. Statistical Abstract of Manipur 2004, Directorate of Economics and Statistics, Government of Manipur.

Barwal, R.N., Yein, B.R., Roy, S., Azad Thakur, N.S. 1994. Rice pest: Their status and management in the north Eastern region of India. Indian J. Hill Farming, 7(2): 183-190.

Gunathiliagaraj, K., Kumar, M.G. 1997. Extent of damage and patterns of emergence of overwintering larvae of rice stem borers in Punjab. Indian J. Ecol., 23(2): 104-108.

Mishra, N., Sharma, L.P., Choubey, G., 2010. Prevalance of insect pests on rice in North Eastern Madhya Pradesh. Oryza, 47(1): 66-68.

Paroda, R.S. 2006. Strategy for increasing productivity, growth rate in agriculture. Farmer's Forum, 6(8): 26.

Peter, A.C., Ooi. 2015. Common insect pests of rice and their natural biological control, an illustrated guide to the insect pests that feed on rice plants and the organisms that feed on and control those pests. Utar Agri. Sci. J., 1(1): 49-59.

Ram, S., Sachan, J.N., Pathak, K.A. 1981. Insect pests of crops in Manipur. Res.Bull. No. 12, ICAR Res. Complex for NEH Region, Shillong pp.17-23. 
Int.J.Curr.Res.Aca.Rev.2016; 4(4): 44-50

Ramzan, M., Hussain, S., Akhter, M. 2007.

Rice Research Institute Kala Shah Incidence of insect pests on rice crop Kaku, J. Anim. Pl. Sci., 17(3-4): 67under various nitrogen doses, PARC 69.

Rice Programme Kala Shah Kaku

\section{How to cite this article:}

Jenita, Th D.C. Ray, Singh,K.I., S.Sanjay Singh and Rocky, Th. 2016. Study of the Insect Pest Complex of Rainfed Rice Crop-Ecosystem of Manipur Valley. Int.J.Curr.Res.Aca.Rev.4(4): 44-50. doi: http://dx.doi.org/10.20546/ijcrar.2016.404.005 